\title{
Pengaruh pemberian pupuk kandang ayam dan pupuk cair urin sapi terhadap pertumbuhan tanaman sawi (brasissca juncea L)
}

Muhammad Yunus ${ }^{1}$, muhammad Arafah., SP,MP ${ }^{2}$ Aswin Bovita., SP ${ }^{2}$

Perogram setudi Agroteknologi Fakultas Pertanian Universitas islam Indragiri

\begin{abstract}
Abstrak
Penelitian tentang pengaruh pemberian pupuk kandang aya dan urin api terhadap pertumbuhan tanaman sawi (brassica juncea L.), penelitian ini telah dilakukan di kelurahan tmbilahan hulu kecamatan temilahan hulu kabupaten Indragiri hilir provinsi riau. Lama penelitian ini berlangsung 3 bulan yaitu mulai dari bulan april sampai bulan juni 2013. Tujuan penelitian ini adalah untuk mengetahui pengaruh pemberian pupuk kandang ayam dan urin sapi baik secara interaksi maupun secara tunnggal dari masing - masing perlaakuan.

Penelitian ini menggunakan rancangan acak kelompok (RAK) secara factorial dengan tiga kali ulangan factor pertama adalah pupuk kandang ayam (PK) dengan tiga kali ulanga. Faktor pertama adalah pupuk kandang ayam $(P K)$ dengan tiga taraf yaitu $P K_{1}=$ pemberian pupuk kandang ayam = 1,8875 kg/plot (15 ton $/$ ha), $P k_{2}=$ pemberian pupuk kandang ayam = $2,5 \mathrm{~kg} / \mathrm{plot}\left(20 \mathrm{ton} / \mathrm{ha}\right.$ ) dan $\mathrm{Pk}_{3}=$ pemberian pupuk kadang ayam =3,125 kg / plot $(25$ ton/ha).

Parameter yang diamati dalam penelitian ini adalah tinggi tanaman,jumlah daun, volume akar,produksi sawi perplot berat segar tanaman dikonsumsi dan berat berangkasan kering.

Hasil yang diperolehh bahwa, interaksi antara pupuk kandnag aya dan urin sapi tidak berpengaruh nyata terhadap tinggi tanaman,jumlah daun, volume,akar perplotberat segar dikonsumsi yang berat berangkasan kering,seddangkan faktor tungal tidak berpengaruh nyata terhadap tinggi tanaman,jumlah daun,volume akar produksi sawi perplotberat segar tanaman dikonsumsi dan berat berangkasan kering.
\end{abstract}

\section{Abstract}

Research on the effect of giving manure and fire urine to the growth of mustard plants (brassica juncea L.), this research has been carried out in the village of Tillahahan Hulu, upstream of Temilahan Hulu, Indragiri, downstream of Riau Province. The duration of this research lasted for 3 months, starting from April to June 2013. The purpose of this study was to determine the effect of giving chicken manure and cow urine both interactively and partially from each treatment.

This study used a factorial randomized block design (RBD) with three replications. The first factor was chicken manure $(P K)$ with three replications. The first factor is chicken manure $(P K)$ with three levels namely $P K 1=$ giving chicken manure $=1.8875 \mathrm{~kg} /$ plot (15 tons / ha), $P k 2=$ giving chicken manure $=2.5 \mathrm{~kg} /$ plot $(20$ tons $/$ ha $)$ and $P k 3=$ fertilizer sometimes chicken $=3.125 \mathrm{~kg} /$ plot ( 25 tons / ha).

The parameters observed in this study were plant height, number of leaves, root volume, mustard plot production, fresh weight of plant consumed and dry weight.

The results obtained that, the interaction between Candlag Fertilizer and cow urine did not significantly affect plant height, number of leaves, volume, root perplotberat, fresh dried dry weight, while the tungal factor did not significantly affect plant height, number of leaves, volume of root production mustard greens perplotberat fresh plants consumed and dry weight perangkot.

Kata Kunci : Media Tanam, Varietas, pertumbuhan dan prodoksi.

\section{PENDAHULUAN}

Tanaman sawi (brassica. L) merupakan tanaman sayur - sayuran yang mudah dibudidayakan di indonnesia.. secara umum tanamaan sawi biasanya mempunyai daun yang panjang, halus, tidak berbulu dan daun tidak berkrop. Petani Indonesia keanyakan hanya 
mengenal tiga macam sawi yang biasa dibudidayakan, yaitu : sawi hiajau,sawi putih dan sawi huma. Sekarang ini masyarakat lebih mengenal caisim alias sawi bakso( Rubatzky dkk,1998)

Tanaman sawi mengandung nutrisi esensial bagi kesehatan tubuh dalam setiap $100 \mathrm{~g}$ berat sawi terkandung protein $2,3 \mathrm{~g}$, lemak $0,3 \mathrm{~g}$, karbohidrat 4,0 g, ca $220 \mathrm{mg}$, fe 2,9 $\mathrm{mg}$, vitmin A $1,94 \mathrm{mg}$, vitamin B 0,09 mg,vitamin C 1,02 mg(dinas tanaman pangan provinsi riau, 2003)

Sawi sangat potensial untuk dibudidayakan karena tingginya kebutuhan masyarakat akan sawi. Hal ini terjadi seiring ddengan meningkatya pengetaahuan masyarakat akan pentingnya manfaat sayuran bagi kessehatan dan pertambahan penduduk, sehinga permintaan pasar akan sayuran meningkat (susilawati,,2005), searang ini produk sayuran yang di inginkan oleh konsumen adalah ayuran yang berkualitas baik dan sehaat serta aan untuk di kosumsi. Untuk mendapatkan sawi dengan kualitas yng baik maka budidaya sawi perlu dillakukan secara alami yaitu meningkatkan pemberian pupuk organic dan mengurangi pemberian pupuk anorganik.

Sutejo (2002) pupuk organic mempunyai fungsi yang penting dibandingkan dengan pupuk anorganik yaaitu dapat menggemburkan lapisan permukaan tanah (topsoil), mmeningkatkan populasi jasad renik, mempertinggi kesuburan tanah haryanto (2003) mengatakan bahwa tanaman sawi membutuhkan pupuk kandnag ayam sebanyak 10 - 20 ton / ha.

Meskiun andungan unsure hara yang rendah, kotoran ayam penting dalam menyediakan hara makro dan mikro seperti $\mathrm{Zn}, \mathrm{Cu}, \mathrm{Mo}, \mathrm{Co}, \mathrm{Ca}, \mathrm{Mg}$, dan ion logam untuk membentuk senyawa kompleks, sehingga ion logam yang meracuni tanaman atau menghambat penyediaan hara seperti $\mathrm{Al}$,Fe dan $\mathrm{Mn}$ dapat dikurangi.

Usur N sangat dibutuhkan oleh tanman untuk proses pembentukan protein. Protein yang dihasilkan akan mendukung pertumbuhan lebaar dan memberukan warna hijau daub (klorofil) yang berperan dalam proses fotossintessiss, mempercepat pertmbuhan tinggi cabang dan batang tanaman. Sumber unsur $\mathrm{N}$ organic yang digunakan juga terdapat pada urin sapi (Lingga,2005) urin sapi merupakan limbah ternak yang mengandung unsure N,P dan $\mathrm{K}$ serta auksin jenis indole butirt Acid (IBA) dan senyawa hidrohgen(Badwell,1974).

Penelitian ini bertujuan untuk mengetehau adanya interaksi pemerian pupuk kandang ayam dan urin sapi terhadap pertumbuhan tanaman sawi,untuuk mengetahui pengaruh pemberian pupuk kandang ayam dan urin sapi yang terbaik terhadap pertumbuhan dan hassil produski tanaman sawi

\section{TINJAUAN PUSTAKA}

Tanaman sawi telah dikenal masyarakat sebaga tanman daun (setiawan 1994), daerah asal tanaman sawi diduga dari tiongkok (China) dan asia timur yang kemudian menyebar luas ke fhilipina dan Taiwan. Beraawal ari kedua Negara tersebut, sawi makin luas dibudidayakan dibelahan dunia lainnya. Tanaman sawi masuk keindonessia pada abad ke - 19 yang dibawa oleh peddagang - peagang luar negeri yang kemudian dikembangkan keseluruh daerah - daerah yang potensial di Indonesia ( Rukmana, 1994) .

Sistemaatika tanaman sawi dapat diklasifikasiikan sebagai berikut : kingdom:

plantae,Divisi:spermathophyta,subdivis o:angiospermae,kelas: dicotylodonae, ordo : rheodales, family: cruciferae (brassicaceae), genus : brassisca, spesies : brassisca juncea. L ( haryanto dkk,2003).

Tanaman sawi dapat tumbuh di aerah yng berssuhu panas maupun berssuhu dingin, sehingga dapat diusahakan di daerah rendah maupun daerah tinggi. Sawi dapat tumbuh baik pada tanah yang gembur dan kaya bahan organic. Selain itu tanahnya harus memiliki drainase yang baik dengan nilai pH 6-7 (nazaruddin,2000). Daerah penanaman yang baik untuk pertumbuhan sawi adalah dari ketinggiaan $5 \mathrm{~m}$ sampai $1200 \mathrm{~m}$ dpl (dari permukaan laut). Namun biasanya tanaman ini dibudidayakan didaerah dengan ketinggiann antara $100 \mathrm{~m}$ sampai $500 \mathrm{~m}$ dpl (haryanto,2003)

Keberhasilan pertumbuhan dan perkembangan tanaman sayur sayuran dilapangan juga ditentukan 
oleh persemaian. Agar tanaman persemaian terhindar dari hujaan dan ssinaar matahari langsung maka perlu di buat naungan pemeliharan tanaman di perseemaian perlu dilaakuakan untuk menjaga agar bibit senantiasa berada ddalam keadaan sehat dan terhindar dari serangan hama dan penyakit perssemaian dilakukan selama 2 minggu dengan daun berjumlah 2-3 helai kemudian dipindahkan kelaapangan(sutarya dan gruben,2002) Pupuk merupakan sumber hara bagi tanmana dengan pemberian puppuk yang cukup maka tanman akan tumbuh baik dan subur sabihan $d k k_{,}(1990)$. Pupuk kandang tergolong dalam pupuk organic yang berasal dari campuran kotoran padat (focces) dan kotoran cair (urin) yang tercampur dari sisa - sisa makanann dan hamparan alas kandnag ternak (sarief, 1993). Pupuk kandnag ayam termasuk kedalam pupuk panaas, dimana proses penguraian pupuk tersebut jasad renik tanah yang berlangsung dengan cepat dan mmengandung seddikit air sehingga terbenuk panas (sutejo,2002). Selanjutnya (soewiti, 1992) menambahkan, bahwa pupuk kandnag yang baru diangkat dari kandnag biasanya masih mempunyai suhu yang agak tinggi, oleh sebab itu tidak boleh langsug dibenamkan kkedalam tanah didekat perakaran. Pupukk kandnag yang sudah masak mempunyai cirri cirri warna kehitam - hitaman, ssuhunya tidak panas dan mudah ditaburkan.

Manfaat pemberian pupuk kandnag banyak sekali antara lain : menyuburkan tanah dan enambah unsure hara tanaman memperbaiki struktur daya mengikat air dan porosistas tanah menambah kandungan bahan organiik memperbaiki kkehidupan mikro organisme tanah, dan melindung tanah dari kerusakaan akibat erosi (haryato,1996). Pupuk kandnag yang berasal dari kotoran ayam padat mengandung $1,00 \% \quad \mathrm{~N}, \quad 0,10 \mathrm{P}$, dan $0,45 \% \mathrm{~K}$, tidak semua unsure hara tersebut dapat dimanfaatkan oleh tanamn karena sebagian hilang sewaktiu pengolahan. Kehilangan tersebut terutama karena pencucian serta dekomposisi aerob dan anaerob (marsono dan sight,2008)

\section{METODOLOGI PENELITIAN}

\subsection{Waktu Dan Tempat}

Penelitian ini dilaksanakan di kebun percobaan fakultas pertaniann beralamat dijalan provinsi parit 1 kecamatan tembilahan hulu kabupaten Indragiri hilir provinsi riau. Jadwal kegiatan penelitian dapat dilihat pada lampiran 1. Pelaksanaan penelitian ini dilkakukan dari bulan april sampai juni 20113.

\subsection{Bahan Dan Alat}

Bahan - bahan yang telah digunakan dalam penelitian ini adalah benih ssawi hijau varietas tosakan, pupuk kkandang ayam, urin ssapi,EM4,larutan gula pekat, air, pasir dan tanah.

Peralatan yang digunakan meeliputi alat penyiraman(gembor), alat ukur(jngka sorong, meteran atau penggaris), alat tulis, hand sprayer,timbangan, timbangaan

analitik,tali,garu,cangkul,parang,dan sabit

\subsection{Metode Penelitian}

Penelitian ini dilakukan secara ekperimmen dengan menggunakan rancanga acak kelompok (RAK) yang terdiri dari 2 faktor adalah:

Factor pertama adalah pemberian pupuk kandang ayam (PK) yang terdiri dari :

PK1 = pemberian pupuk kandnag ayam $=1,875 \mathrm{~kg} /$ plot (15 ton $/ \mathrm{ha}$ )

$\mathrm{PK} 2=$ pemberian pupuk kandang ayam $=2,5 \mathrm{~kg} / \mathrm{plot}$ (20 ton $/ \mathrm{ha}$ )

$\mathrm{PK} 3=$ pemberian ppupuk kandang ayam $=3,125 \mathrm{~kg} / \mathrm{plot}$ ( 25 ton/ha).

Factor kedua adalaah pemberian urin sapi (U) yang terdiri dari :

$\mathrm{UI}=$ pemberian urin sapi $\mathrm{L}^{-1}$ air disemprot ke daun

$\mathrm{U}_{2}$ = pemberian urin sapi $50 \mathrm{Ml} \mathrm{L}^{-1}$ air disemprot kedaun

$\mathrm{U}_{3}=$ pemberian urin sapi $25 \mathrm{~mL} \mathrm{~L}^{-1}$ air disemprot ke tanah

$\mathrm{U}_{4}=$ pemberian urin sapi $50 \mathrm{~mL} \mathrm{~L}^{-1}$ air disemprot ketanah.

Dari kedua factor diatas didapat 12 kombinasi perlakuan,maasing masing perlakuan diulang 3 kali sehingga diperoleh 36 unit percobaaan, setiap unit percobaan terdiri dari 720 tanaman. Denah plot percobaan dapat dilihaat pada lampiran 3. 
Denga demikian diperoleh 12 kobinasi perlakuan ddengan 3 ulangan dalam setiap kombinaasi dan jumlah unit percobaan sebanyak 36 satuan percobaan, seperti terliat pada table 1 .

Table 1. kombinasi perlaakuan penelitian

\begin{tabular}{|c|c|c|c|c|}
\hline $\begin{array}{c}\text { Pupuk } \\
\text { kandna } \\
\text { g ayam }\end{array}$ & \multicolumn{4}{|c|}{ Urin sapi } \\
\cline { 2 - 5 } & $\mathrm{U}_{1}$ & $\mathrm{U}_{2}$ & $\mathrm{U}_{3}$ & $\mathrm{U}_{4}$ \\
\hline
\end{tabular}

\begin{tabular}{|c|c|c|c|c|}
\hline \multirow{2}{*}{$\begin{array}{l}\text { Perlakuan } \\
\text { varietas }\end{array}$} & \multicolumn{3}{|c|}{ Tanah } & \multirow{2}{*}{$\begin{array}{l}\text { Rata- } \\
\text { rata }\end{array}$} \\
\hline & gambut & PMK & Aluvial & \\
\hline \multicolumn{5}{|c|}{............................. } \\
\hline Simoleh & 58,33 & 58,66 & 57,33 & \multirow{5}{*}{$\begin{array}{l}58,11 a b \\
57,88 a b \\
58,22 a \\
57,33 b\end{array}$} \\
\hline NT 10 & 57,66 & 58,33 & 57,66 & \\
\hline N 35 & 57,66 & 58,00 & 59,00 & \\
\hline mitro & 57,33 & 57,66 & 57,00 & \\
\hline Rata-rata & $57,75 a$ & $58,16 a$ & $57,75 a$ & \\
\hline $\mathrm{PK}_{1}$ & $\mathrm{PK}_{1} \mathrm{U}$ & $\mathrm{PK}_{1} \mathrm{U}$ & $\mathrm{PK}_{1} \mathrm{U}$ & $\mathrm{PK}_{1} \mathrm{U}_{4}$ \\
\hline $\mathrm{PK}_{2}$ & & & & $\mathrm{PK}_{2} \mathrm{U}_{4}$ \\
\hline \multirow[t]{4}{*}{$\mathrm{PK}_{3}$} & $\mathrm{PK}_{2} \mathrm{U}$ & $\mathrm{PK}_{2} \mathrm{U}$ & $\mathrm{PK}_{2} \mathrm{U}$ & PK3U \\
\hline & & & & 4 \\
\hline & $\mathrm{PK}_{3} \mathrm{U}$ & $\mathrm{PK}_{3} \mathrm{U}$ & $\mathrm{PK}_{3} \mathrm{U}$ & \\
\hline & 1 & 2 & 3 & \\
\hline & & & & \\
\hline
\end{tabular}

Data yang diperoleh di analisis dengan menggunakan sidik ragam berdasakan linear ssebagai berikut

$$
\text { Yijk }=u+u i+P K j+P K U j k+\sum i j k
$$

Yijk = hasil pengamatan

$\mu \quad=$ nilai tengah

$\mathrm{Ui} \quad=$ pengaaruh ulangan ke $\mathrm{i}$

$\mathrm{PKj}=$ pengaruh perlakuan pupuk kandnag ayam pada taraf ke - $j$

Uk = pengaruh perlaakuan urin sapi pada taraf ke $-\mathrm{k}$

PKUjk = pengaruh interaksi antara pupuk kandang ayam ke - j dan urin sapi ke - $k$

$\sum i j k=$ pengaruh galat prcobaan pada ulangan ke-I dengan mendapat perlakuan pupuk kandnag ayam taraf ke - j dan urin sapi taraf ke- k.

Data diolah secara statistic apabila menunjukan berbedda nyata dilanjutkan ddnegan uji Tukey HSD 5\%

\subsection{Pelaksanaan Penelitian}

Media persemaaian adalah tanah yaitu dengan membuat plot yang berukura $1 \mathrm{mx} 1 \mathrm{~m}$ dengan ketebalan $5 \mathrm{~cm}$ yang telah diberi pupuk dassar berupa pupuk kanddnag ayamsetelah itu mencampurkan benih sawi dengan pasir gula tidak menggumpal, dengan perbandingaan 1: 5 dan ditevarkan pada media persemaian. Kegiatan ini dilakukan 2 miggu sebelum penanamaan. Semaian yang yang telah beruur 14 hari dipindahkan kemedia tanam dengan cara mengambil bibit satu persatu secara hati - hatti dengan menggunakan seed tray agar akan tanaman tidak putus.

\section{DAN PEMBAHASAN}

\subsection{Tinggi tanaman (cm)}

Analisis sidik ragam menunjukan bahwa intraksi perlakuan media tanam dan varetas berpengarauh tidak nyata tyerhadap tinggi tanam, akan tetapi perlakuan media tanam pengaruh tidak nyata terhadap tinggi tanaman (lampiran 4a).hasial analisis stastikyang diuji lanjut dengan BNJ pada taraf $5 \%$ dapat di lihat

pada tabel 2.

Tabel 2.

Rata-rata pengaruh berbagai media tanah dan beberapa varietas Terhadap tinggi tanam.

\begin{tabular}{|l|l|l|l|l|}
\hline \multirow{2}{*}{$\begin{array}{l}\text { Perlakuan } \\
\text { varietas }\end{array}$} & \multicolumn{3}{|c|}{ Tanah } & $\begin{array}{l}\text { Rata- } \\
\text { rata }\end{array}$ \\
\cline { 2 - 4 } & gambut & \multicolumn{4}{|c|}{ PMK } & Aluvial & \\
\hline Simoleh & 194.67 & 215.33 & 190.00 & $200,00 \mathrm{~b}$ \\
NT 10 & 205.67 & 202.00 & 203.67 & $203,78 \mathrm{~b}$ \\
N 35 & 200.67 & 1983.33 & 222.67 & $207,22 \mathrm{~b}$ \\
mitro & 245.00 & 226.67 & 241.00 & $237,56 \mathrm{a}$ \\
\hline Rata-rata & $211.50 \mathrm{a}$ & $210.33 \mathrm{a}$ & $214.33 \mathrm{a}$ & \\
\hline
\end{tabular}

Keteranagn : angka-angka pada kolomdan baris yang di ikuti oleh huruf kecil yang tidak sama berbeda nyata pada taraf 5\% uji BNJ

Dari tabl 2 menunjukan jenis-jenis varietas menghasilkan tinggi tanaman tertinggi yaitu $237,56 \mathrm{~cm}$ dan berbeda nyata dengan varietas N35 yaitu $207,22 \mathrm{~cm}$, NT 10 yaitu $203,78 \mathrm{~cm}$ dan simoleh yaitu $200,00 \mathrm{~cm}$ merupakan tanamn tertinggi.

\subsection{Luas Daun (cm)}

Analis sdik ragam menunjukan bahwa penggunaan media tanam dan varietas berpengaruh tidak nyata terhadap luas daun, akan tetapi perlakuan varieetas secara tunggal pengaruh tidak nyata terhadap luas daun (lampiran 4b). Hasil analisil stastik yang diuji nlanjut dcebgan BNJ pada taraf 5\% dapat di lihat pada tabel 3

Tabel 3. Rata-rata pengaruh berbagai media tanah dan beberapa varietas terhadap luas daun.

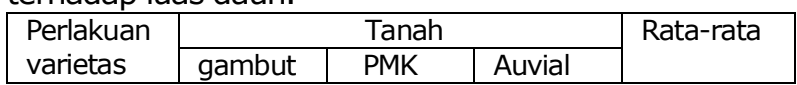




\begin{tabular}{|c|c|c|c|c|}
\hline Simoleh & 606.25 & 615.37 & 719.67 & $647.10 a$ \\
\hline NT 10 & 685.00 & 615.00 & 718.53 & $672.19 a$ \\
\hline N 35 & 700.33 & 630.00 & 734.23 & $688.19 a$ \\
\hline mitro & 644.00 & 710.04 & 763.33 & $705.79 a$ \\
\hline Rata-rata & $658.90 \mathrm{~b}$ & $624.60 \mathrm{~b}$ & $733.94 a$ & \\
\hline
\end{tabular}

Keterangan : angka-angka pada kolom dan baris yang dikuti oleh huruf kecil yang tidk sama berbeda nyata pada taraf $5 \%$ UJI BNJ

Dari tabel 3 menunjukan luas daun tertinggi diperoleh pada variertas mitro yaitu $705.79 \mathrm{~cm}$ dan berbeda tidak nyata dengan perlakuan varietas simoleh (647.10 $\mathrm{cm})$, yang merupakan luas daun terendah. Luas daun tana man di pengaruhi oleh faktor internal faktor internal meliputi genetik dari varietas itu sendir, sedangkan faktor ekstrnal adalah linkungan yang meliputi penyinaran matahar, curah hujan suhu kelembaban dan kecepatan angin.

\subsection{Umur Berbunga (HST)}

Amalisis sidik ragam menunjukan bahwa tanamandan varetas pengaruh tidak nyata terhadap umur berbunga, perlakuan media tanam pengaruh tidak nyata terhadap umur berbunga, akan tetapi perlakuan varietas secara tunggal berpengaruh nyata terhadap umur berbunga, akan (lampiran 4c). Hasil analisis stastik yang di uji lanjut dengan BNJ pada taraf 5\% dapat di lihat pada tabel 4.

Keterangan :angka-angaka pada kolom dan baris yang diikuti oleh hurup kecil yang tidak sama berbeda nyata pada taraf 5\% UJI BNJ

Dari tabel 4 menunjukan bahwa umur berbungga tercepat terdapat pada 58,22 HST yang merupakan umur berbungga terlama, akan tetapi varietas NT 10 dan varietas jagung mais tidak berbeda nyata terhadap umur berbungga.

\subsection{Diameter tongkol}

Analisis sidik ragam menunjukan bahwa intraksi penggunan berbagai media tanam terhadap beberapa varietas berpengaruh tidak nyata terhadap diameter tongkol, (lampiran 4d). Hasil analisil stastik yang di uji lanjut dengan BNJ pada taraf $5 \%$ dapat di lihat pada tabel 5.

Tabel 5. Rata-rata pengaruh berbagai media tanah dan beberapa varietas terhadap terhadap diameter tongkol

\begin{tabular}{|c|c|c|c|c|}
\hline \multirow{2}{*}{$\begin{array}{l}\text { Perlakuan } \\
\text { varietas }\end{array}$} & \multicolumn{3}{|c|}{ Tanah } & \multirow{2}{*}{$\begin{array}{l}\text { Rata- } \\
\text { rata }\end{array}$} \\
\hline & gambut & PMK & Aluvial & \\
\hline \multicolumn{5}{|c|}{$\ldots \ldots \ldots \ldots \ldots \mathrm{cm} \ldots \ldots \ldots \ldots$} \\
\hline Simoleh & 2.53 & 2.73 & 3.03 & 2.76 \\
\hline NT 10 & 3.00 & 3.06 & 3,06 & $\mathrm{~b}$ \\
\hline N 35 & 2.93 & 2.63 & 3.30 & 3,04 \\
\hline mitro & 2.26 & 2.90 & 3.70 & $\begin{array}{l}a b \\
2.95 \\
a b \\
3.28 \\
a\end{array}$ \\
\hline
\end{tabular}

\begin{tabular}{|l|l|l|l|l|}
\hline Rata-rata & $\begin{array}{l}2.93 \\
\mathrm{ab}\end{array}$ & $\begin{array}{l}2.83 \\
\mathrm{a}\end{array}$ & $\begin{array}{l}3,27 \\
\mathrm{a}\end{array}$ & \\
\hline
\end{tabular}

Keterangan: angka-angka pada kolom dan baris yang diikuti oleh huruf kecil yang tidak sama berbeda nyata pada taraf 5\% UJI BNJ.

Dari tabel 5 menunjukan perlakuan varietas mitro menghasilkan diameter tongkol sebesar yaitu3,28 cm dan berbeda tidak nyata dengan varietas jagung manis berbeda tidak nyata terhadap varietas N 35 dan NT 10.

Tiap-tiap varietas mempunyai potensi genetik yang berbeda-beda. Hal ini mengakibatkan setiap varietas berbedabeda sifatnya dalam pertumbuhan maupun produksi.satu varietas akn mampu meghasilkan potensi genetiknya, apabila di tanam pada kondisi lingkungan yang sesuai.

\subsection{Jumlah Biji per Tongkol}

Analisis sidik ragam menunjukan bahwa intraksi media tanam dan varietas berpengarauh tidak nyata terhadap jumlah biji per tongkol, perlakuan media tanam secara tunggal pengaruh tidak nyata terhadap jumlah biji, akan tetapi perlakuan varietassecara tunngal memberikan pengaruh yang nyata terhadap jumlah biji per tongkol (lampiran 4e). Hasil analisis stastik yang di uji lanjut dengan BNJ pada taraf $5 \%$ dapat di lihat pada tabel 6 .

T6abel 6. Rata-rata pengaruh berbagai media tanam dan beberapa varietas jagunga terhadap jumlah biji per tongkol.

\begin{tabular}{|c|c|c|c|c|}
\hline \multirow{2}{*}{$\begin{array}{l}\text { Perlakuan } \\
\text { varietas }\end{array}$} & \multicolumn{3}{|c|}{ Tanah } & \multirow[t]{2}{*}{ Rata-rata } \\
\hline & gambut & PMK & Aluvial & \\
\hline \multicolumn{5}{|c|}{$. . \mathrm{cm} . . . \ldots \ldots \ldots$} \\
\hline Simoleh & 271.00 & 262.67 & 214.00 & \multirow{5}{*}{$\begin{array}{l}258.56 \mathrm{~b} \\
284.89 a b \\
262.56 \mathrm{~b} \\
332.89 a\end{array}$} \\
\hline NT 10 & 295.33 & 298.00 & 261.33 & \\
\hline N 35 & 282.33 & 217.00 & 288.33 & \\
\hline Mitro & 287.67 & 342.67 & 369.00 & \\
\hline Rata-rata & $284.33 \mathrm{a}$ & $279.92 \mathrm{a}$ & $289.92 \mathrm{a}$ & \\
\hline
\end{tabular}

Keterangan : angka-angka pada kolom yang diikuti oleh huruf kecil yang tidak sama berbeda nyata pada taraf 5\% UJI BNJ dari tabel 6 menunjukan perlakaun varietas mitro menghasilkan jumlah biji terbesar yaitu 33.89 biji dan berbeda nyata dengan varietas simoleh yaitu 258.56 biji yang merupakan jumlah biji terendah, akan tetapi jumlah biji varietas $\mathrm{N} 35$ tidak berbeda nyata dengan varietas $\mathrm{N} 10$ dan jagung manis.tejadinya perbedaan yang nyata antara varietas yang satu dengan vaeietas yang lain di sebabkan oleh faktor linkungan dan jenis varietas yang di gunakan. 


\section{6 roduksi tanaman sawi}

Analisis sidik ragam menunjukan bahwa intraksi media tanam dan varietas berpngaruh tidak nyata terhadap produksi. Perlakuan media tanaman secara tunggal pengaruh tidak nyata terhadap produksi kering,akan tetapi perlakuan antar varietas secara tunggal memberikan pengaruh nyata terhadap produksi kering (lampiran 4f). Hasil analisis statistik yang di uji lanjut dengan BNJ pada taraf 5\% dapat dilihat pada tabel 7.

Tabel 7.pengaruh berbagai media tanah dan beberapa varietas jagung terhadap produksi .

Keterangn : Angka-angka pada kolom dan baris yang di ikuti oleh huruf kecil yang tidak sama bebeda nyata pada taraf 5\% UJI BNJ.

Dar tabel 7 menunjukan bahwa produksi kering tertinggi di peroleh pada varietas mitro yaitu $182.77 \mathrm{~g}$ dan berbeda nyata dengan varietas simoleh yaitu 91,00 yang merupakn produksi kering. Jenis varietas merupakan salah satu fakrtor yang mempengaruhi daya hasil jagung. Keampuan tanaman untuk mengahasilkan produksi ditentukan oleh faktor genetis, fakrtor linkungan dan intraksi sifat-safat genetis akan muncul secara utuh jika faktor lingkungan mendukung.

\subsection{Bobot 1000 biji}

Analisis sidik ragam menunjuykan bahwa intraklsi media tanam dan varietas berpengaruh tidak nyata terhadap bobot 1000 biji, perlakuan media tanam secara

tunggal pengaruh tidak nyata terhadap bobot 1000 biji akan tetapi perlakuan antar varietas secara tunggal memberikan pengaruh nyata terhadap bobot 1000 biji (lampiran $4 \mathrm{~g}$ ). Analisis stastik yang di uji lanjut dengan BNJ pada taraf $5 \%$ dapat di lihat pada tabel 8.

Berdasarkan penelitian yang di lakukan, maka dapatdi simpulkan bahwa:

Intraksi antara mediatanam dan beberapa varetas jagung tidak berpengaruh nyata terhadap pramenyer tinggi tanamaan, luas daun, umur berbungga, diameter tongkol, jumlah biji per tongkol peruduksi kering sereta bobot 1000 biji.

Tabel 8 pengaruh berbgai media tanah dan beberapa varietas jagung terhadap 1000 bobot biji.

\begin{tabular}{|l|l|l|}
\hline Perlakuan & Tanah & Rata-rata \\
\hline
\end{tabular}

\begin{tabular}{|c|c|c|c|c|}
\hline varietas & gambut & PMK & Aluvial & \\
\hline \multicolumn{5}{|c|}{ 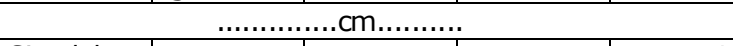 } \\
\hline Simoleh & 220 & 196.6 & 250 & $222.2 \mathrm{~b}$ \\
\hline NT 10 & 233.3 & 236.6 & 246,6 & $238.8 b$ \\
\hline N 35 & 230 & 206.6 & 246,6 & \\
\hline mitro & 270 & 280 & 263,3 & $271.1 \mathrm{a}$ \\
\hline Rata-rata & $238.32 a$ & $229.95 a$ & $251,62 a$ & \\
\hline \multirow{10}{*}{\multicolumn{5}{|c|}{$\begin{array}{l}\text { Keterangan : Angka-angka pada kolom dan } \\
\text { baris yang diikuti oleh huruf kecil tidak sama } \\
\text { berbeda nyata pada taraf } 5 \% \text { UJI BNJ. } \\
\text { Dari tabel } 8 \text { menunjukan bahwa bobot } \\
1000 \text { biji tertinggi diperoleh pada } \\
\text { varietas mitro yaitu } 271,1 \mathrm{~g} \text { dan } \\
\text { berbeda nyata dengan varietas simoleh } \\
\text { yaitu } 222,2 \mathrm{~g} \text { yang merupakan bobot } \\
1000 \text { biji terendah, akan tetapi varietas } \\
\text { N35 jagung manis dan NT } 10 \text { berbeda } \\
\text { tidak nyata terhadap bobot } 1000 \text { biji, } \\
\text { bobot } 1000 \text { biji merupakan minefestasi } \\
\text { dari kemampuan tanaman untuk }\end{array}$}} \\
\hline & & & & \\
\hline & & & & \\
\hline & & & & \\
\hline & & & & \\
\hline & & & & \\
\hline & & & & \\
\hline & & & & \\
\hline & & & & \\
\hline & & & & \\
\hline $\begin{array}{l}\text { mengh } \\
\text { karbohi }\end{array}$ & & & & \\
\hline
\end{tabular}

\section{KESIMPULAN DAN SARAN}

Berdasarkan penelitian yang di lakukan, maka dapatdi simpulkan bahwa:

Intraksi antara pemberian pupuk kandang ayam dan pupuk urin sapi dan beberapa varetas sawi tidak berpengaruh nyata terhadap pramenyer tinggi tanamaan, luas daun, umur berbungga, diameter,Pada penelitian ini tanah yang paling bagus adalah tanah aluvial dan jenis varietas terbaik yaitu varietas mitro baik pada masa pertumbuhan sampai ke produksi.

\section{DAFTAR PUSTAKA}

Annonimous. 2008 Badab pusat statistik Harvested Area, yield rate and production of mayze by province, 2006-2007. www,bps.go.id. dikutip 28 februari 2008.

Rukmana. (1997). usaha tani jagung. yogyakarta.

Irfan, m.1999.respon tanaman jagung (brasissca juncea L) terhadp pengolahan tanah dan kerapatan tanah pada tananh andisol dan ultisol. Pasca sarjana universitas utara. Medan. Hal 7-13

Soepardi. G. 1983. Sifat dan ciri Tanah. Jurusan ilmu tanah. Insitut pertanian 
Sarief, S. 1986. Ilmu tanah pertanian. Pustaka buana bandung. 